\title{
Landslide Hazard Mapping of Nagadhunga-Naubise Section of the Tribhuvan Highway in Nepal with GIS Application
}

\author{
Arjun Raj Pandey1, Farzad Shahbodaghlou² \\ ${ }^{1}$ Department of Civil, Architectural, and Environmental, Illinois Institute of Technology, Chicago, USA \\ ${ }^{2}$ Departmant of Engineering, California State University, East Bay, Hayward, USA \\ Email: apandey2@hawk.iit.edu, farzad.shahbodaghlou@csueastbay.edu
}

Received 27 October 2014; revised 27 November 2014; accepted 18 December 2014

Copyright (C 2014 by authors and Scientific Research Publishing Inc.

This work is licensed under the Creative Commons Attribution International License (CC BY).

http://creativecommons.org/licenses/by/4.0/

(c) (i) Open Access

\begin{abstract}
The aim of this project was to prepare and study a hazard map of Nagadhunga-Naubise section of the Tribhuvan highway. This section lies in the Middle Mountain region of Nepal. For the preparation of the hazard map of the corridor three steps, initial study, field investigation, and data analysis and presentation were carried out. In the initial study, the collection of available data and review of the literature were done. The base map was then prepared from the topographical map. In the field investigation step, all information and maps prepared earlier in the initial study were verified by field check. In the final step, prepared and verified data were then analyzed for the hazard mapping. Topography (gradient, slope shape and slope aspect), geology, drainage and landuse were considered to be the major influencing factors in the slope stability. Pre-assigned hazard rating method was used for hazard mapping of the study area. The area was divided into equal facets. Then ratings of responsible factors to the hazard were assigned to each facet and overlaid based upon a predetermined rating scheme. Total estimated hazard was the sum of these ratings for each overlay. Hazard map was prepared by using three categories as low hazard, medium hazard and high hazard. The Geographic Information System (GIS) was the main tool for the data input, analysis, and preparing of the final hazard map. The hazard map showed the areas of different hazard potential classes of; "low" with $32 \%$ portion, "Medium" with $51 \%$, and "high" with $17 \%$ portion.
\end{abstract}

\section{Keywords}

Geology, Topography, Hazard Map, Hazard Rating, GIS (Geographic Information System) 


\section{Introduction}

Nepal is a mountainous country of geologically young mountains [4] [5]. Generally roads and other linear structures are laid along the steep hill slopes. These hill roads are also crossed by numbers of streams and rivers. Tribhuvan highway is also one of the major roads laid on the steep hill slopes, which joins the Capital City to the other parts of the country. Roads laid on such fragile geomorphology are vulnerable to various kinds of disasters [5] [10]. The roads section Nagadhunga-Naubise also experiences frequent slope failures, landslide, and roadblock [6] [7]. The landslide and blockage of the road especially during monsoon season have frequently blocked the traffic movement with numbers of accidents [7]. Landslides have always been a major hazard to the safety of people and their property. The fragile and young Himalayas with torrential monsoon, earth tremors and environmental degradation have together increased occurrence of landslide in Nepal.

Increasing population density and expansion of infrastructure have resulted in changes in natural slope, river morphology, and land-use/land cover. The frequency in the occurrence of the landslides, and flood hazards have been increasing in recent years [2] [5] [6] [10]. This is evidenced by the fact that in Nepal, floods and landslides alone claimed more than 5800 human lives during the period of 1983 to 2003 [8]. The loss of lives, owing to floods, landslides, and avalanches, comprises about $29 \%$ of the total losses from all types of disasters. As a result of increased natural hazards, the magnitudes of lives and property at risk have also increased correspondingly [11] [12].

In this study the Nagadhunga-Naubise road corridor $\left(85^{\circ} 00^{\prime}\right.$ to $85^{\circ} 12.50^{\prime}$ longitude and $27^{\circ} 38^{\prime}$ to $27^{\circ} 48^{\prime}$ latitude), six kilometer square area, $500 \mathrm{~m}$ on either side of the highway section was selected as the study area.

Hence, the identification of hazards/susceptible areas and the concurrent assessment of the risks associated with these hazards become important for devising effective mitigation plans. In this context an attempt has been made to prepare a landslide hazard map of the area.

The preliminary examination of the area showed that 11 landslides of different types and sizes were identified [8]. Out of these, 8 landslides were investigated in more detail during fieldwork. The selection of these slope failures depended upon its severity and impact on infrastructures. The detail investigation of the landslides in the area is to understand the triggering factors of landslide in the area, which ultimately became the basis for the hazard rating. This gave a strong basis for the engineering judgment of the rating of hazards as well.

\section{Research Objectives}

The objective of the study is to prepare a hazard map of the section Nagadhunga-Naubise (500 m either side) road section. The detailed studies of the individual landslide were conducted to understand the landslide triggering factors in order to develop of the system of hazard rating. The study is primarily based on available maps (topographical and geological), aerial photos, visual interpretation and relevant digital imageries and other secondary sources of information. In addition, detailed field surveys were carried out to verify and update the information obtained from maps, aerial photos, and imageries. The Geographic Information System (GIS) technology is the main tool used for data input, analysis, and hazard mapping. Four parameter maps: Topography (gradient, slope shape, slope aspect), Land-use, Geology, and Drainage, were used for landslide hazard mapping [6].

\section{Research Approaches}

This study is done in three parts: Defining a research hypothesis and relevant research questions, conducting a literature review based on the research design, survey and data collection from field and other sources, and analyzing and presenting the research.

There have been several methodologies developed for the Hazard Mapping [1] [5] [6]. These methods can be broadly categorized into three types: Simple qualitative mapping (pre-assigned rating method); Statistical (bivariate and multivariate) method; and Deterministic method. The Statistical and Deterministic method are particularly applied for landslide hazard mapping. The Statistical method is used to prepare the Hazard Map in this study. Arc View is used to produce Digital Elevation Model (DEM) from which several landslide hazard parameters such as slope gradient, slope shape, relative relief, and the drainage density were derived in raster/grid format. 


\subsection{Development of System for Hazard Mapping}

For this study four categories of factors, which contribute landslide, were considered: topography, geology, land use, and river/drainage system. In addition, the category of topography was divided into four sub-groups: respective gradient, vertical profile, horizontal profile, and aspect.

As stated earlier, landslide hazard is governed by the combination of various factors, which have roles of differing importance [6] [11]. Based on relative importance of each factor a numerical weighting (Table 1 column 2) were assigned. The same was done for the sub-groups of topography and geology (Table 1 column 4). The selection of these factors and weights are based on engineering judgment, available statistical data and findings from other studies.

Table 1. Quantification of hazard zonation (Deoja and et al., 1991 [5]; Moser, 2002 [9]; Sarkar and et al., 1995 [10]).

\begin{tabular}{|c|c|c|c|c|c|c|}
\hline 1 & 2 & 3 & 4 & 5 & 6 & 7 \\
\hline Category of Factors & $\begin{array}{l}\text { Weight among } \\
\text { Categories }\end{array}$ & Sub-Group & $\begin{array}{l}\text { Weight Of Sub } \\
\text { Group }\end{array}$ & Global Weight & Criteria & Failure Potentia \\
\hline \multirow[t]{14}{*}{ Topography } & 30 & Gradient & 0.4 & 12.0 & $0-20$ & 0.00 \\
\hline & & & & & $20-25$ & 0.25 \\
\hline & & & & & $25-30$ & 0.50 \\
\hline & & & & & $30-40$ & 0.75 \\
\hline & & & & & $40-90$ & 1.00 \\
\hline & & $\begin{array}{c}\text { Shape of Vertical } \\
\text { Profile }\end{array}$ & 0.4 & 12.0 & Concave & 0.00 \\
\hline & & & & & Straight & 0.50 \\
\hline & & & & & Convex & 1.00 \\
\hline & & $\begin{array}{c}\text { Shape of } \\
\text { Horizontal Profile }\end{array}$ & 0.1 & 3.0 & Concave & 0.00 \\
\hline & & & & & Straight & 0.50 \\
\hline & & & & & Convex & 1.00 \\
\hline & & Slope Aspect & 0.1 & 3.0 & SE, $S$ & 0.00 \\
\hline & & & & & E, W, SW & 0.50 \\
\hline & & & & & NE, NW, N & 1.00 \\
\hline \multirow[t]{3}{*}{ Land Use } & 20 & Land Use Type & 1.0 & 20.0 & Thickly Vegetated & 0.00 \\
\hline & & & & & Forest & 0.50 \\
\hline & & & & & $\begin{array}{l}\text { Cultivated Bari } \\
\text { (Sloping Terrace) }\end{array}$ & 0.60 \\
\hline \multirow[t]{4}{*}{ Geology } & 25 & Lithology & 1.0 & 25 & Colluviums & 0.00 \\
\hline & & & & & $\begin{array}{l}\text { Sopayang Formation } \\
\text { (Dark Argillaceous) }\end{array}$ & 0.60 \\
\hline & & & & & Chandragiri Limestone & 0.5 \\
\hline & & & & & Weak Rocks & 0.7 \\
\hline \multirow[t]{3}{*}{$\begin{array}{l}\text { River/Drainage } \\
\text { System }\end{array}$} & 25 & & 1.0 & 25 & $0-15 \mathrm{~m}$ & 0.00 \\
\hline & & & & & $15-30 \mathrm{~m}$ & 0.25 \\
\hline & & & & & $>30 \mathrm{~m}$ & 0.50 \\
\hline
\end{tabular}


To obtain a comparable global weight (column 5) of each factor, the values of column 2 and 4 were multiplied. Table 1 assigns to the categories of land use, geology and drainage followed by gradient and shape of vertical profile with a global weight value of 12 . Aspect and horizontal profile have lowest importance; hence, their values of 3 .

It should be noted that Table 1 is the tabular form of a two-level decision tree adopted fromre-evaluation of failure potential.

To evaluate the hazard potential of a single cell, a criterion of each sub group was established (Table 1, column 6). These criteria were rated according to third slope failure potential which is listed in column 7 . The values range from 0 to 1 , where the higher the values the higher are the potential slope failure.

\subsection{Procedure for Mapping of Landslide Hazard}

The area in which the mapping was conducted had to be divided into a number of cells. These cells are represented by squares of an area of $5 \mathrm{~m}$ by $5 \mathrm{~m}$. For each cell, the slope failure potential was assessed using the established criteria shown in the Table 1. To obtain the slope failure potential map, data layers for each factor have been produced and superimposed. The development of these maps is described in the following sections. The Figure 1 is the schematic illustration of superimposition of different layers to produce the hazard map.

\section{Findings and Discussions}

The study area is divided into a number of $5 \mathrm{~m}$ by $5 \mathrm{~m}$ cells. The total area covering the section is about $6 \mathrm{~km}^{2}$. Each cell of the area has been rated for its landslide hazard potential based on the criteria in the Table 1 . In other words for each cell seven rating values were assigned.

The final landslide hazard potential value was obtained by adding the seven values of each cell according to Table 1. The values of the failure potential of each cell, which range from 0.5 to 4.4 , are classified into three zones of instability. In order to increase slope stability, terrain was divided into high, medium, and low hazard segments. Based on this classification the hazard map was drawn.

\subsection{Base Map}

There are two maps (Figure 2 and Figure 3) are presented in this section. Figure 2 is the location map of the $\underline{\text { Parameters }} \quad \underline{\text { Overlay }} \quad \underline{\text { Weight Maps }}$

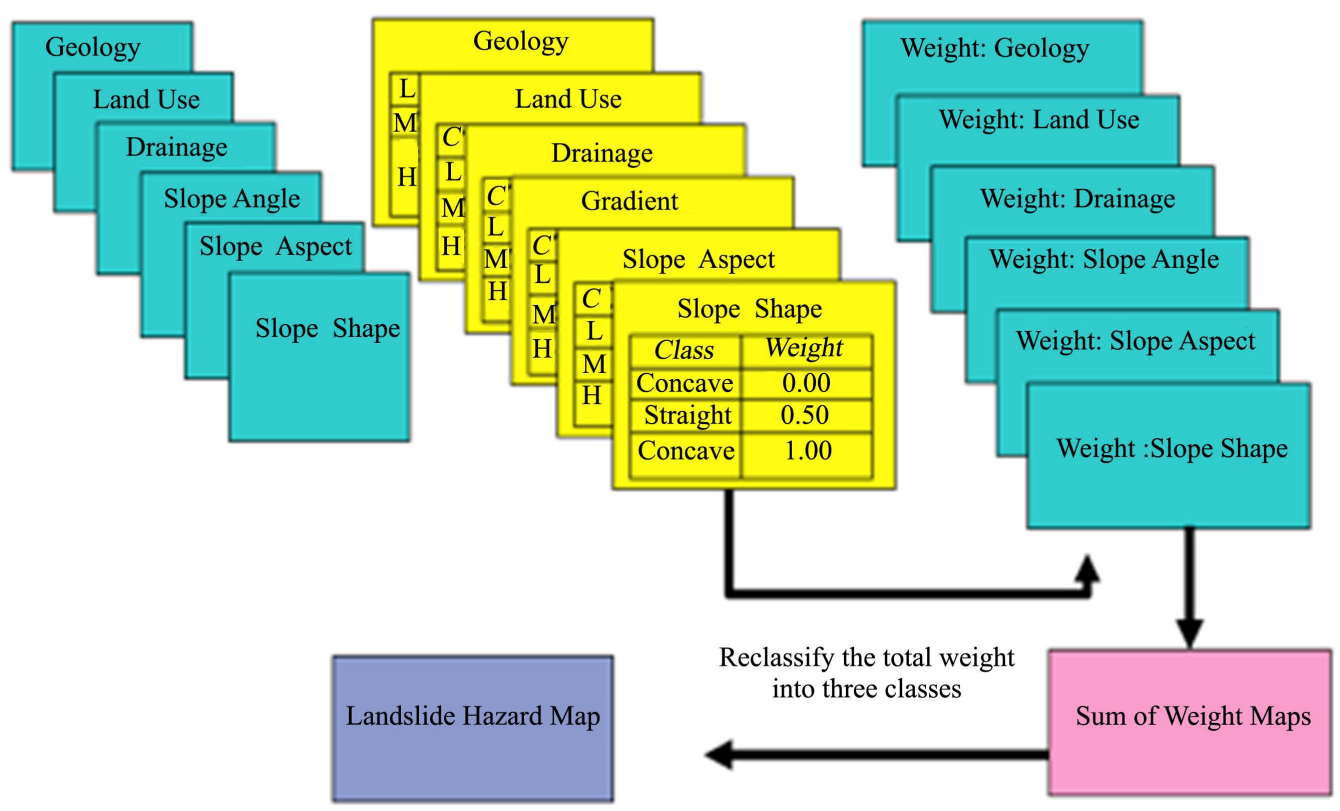

Figure 1. Schematic illustration of superimposition of different layers. 


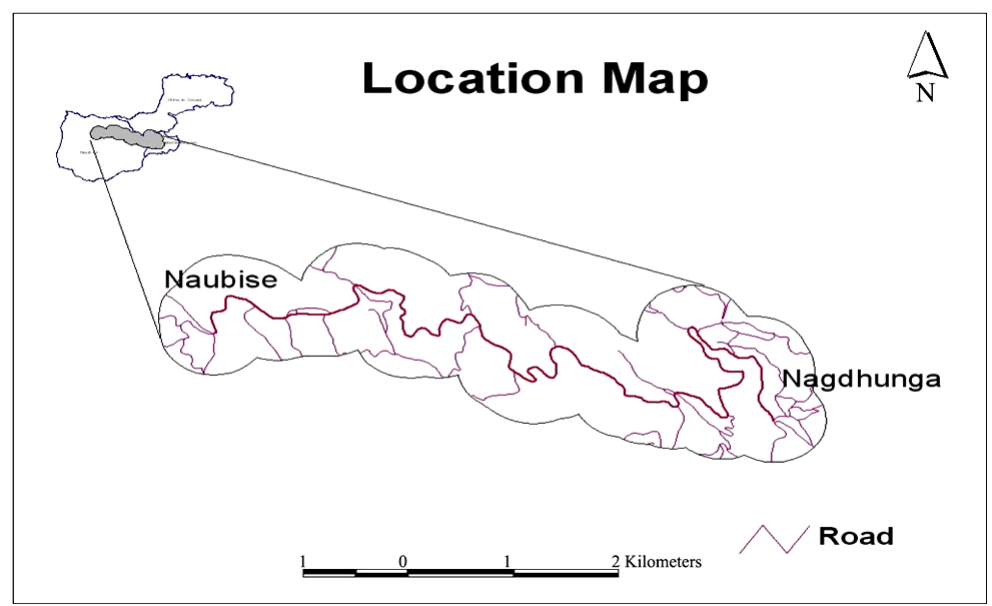

Figure 2. Location map of the study area.

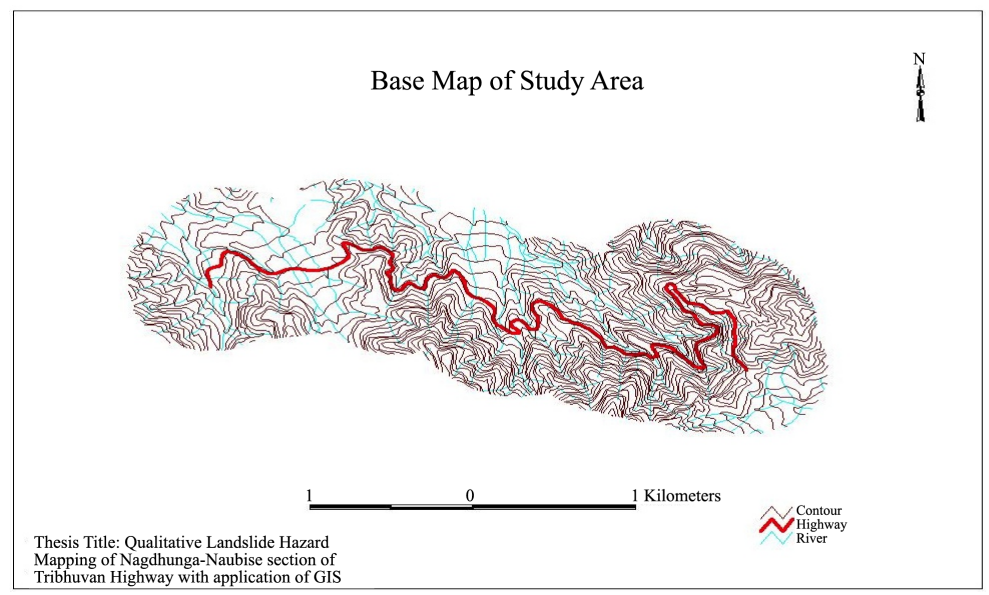

Figure 3. Base map of the study area.

study area. Figure 3 is the base map of the study area, which is a topographic map of the study area.

\subsection{The Geological Map}

The Kathmandu Geological Complex characterizes the geology of the study area. Figure 4 shows the proportion of different geological compositions of the study area. From the Geological Map as shown in Table 2, the large portion of the study area falls 60\% under Chandragiri Limestone, $20 \%$ under Sopyang formation and 12\% under Colluviums. Chandragiri Limestone consists of light limestone, partly siliceous-argillaceous, fine-crystalline, echinoderms. Similarly, Sopyang Formation consists of slate with thin beds of limestone.

\subsection{The Land Use Map}

Non-irrigated sloped terraces and forest-covered slopes are the most found landuse type in the study area as shown in Table 3. Figure 5 shows the Land Use map of the study area.

\subsection{River/Drainage}

Drainage density is an indicator of run-off condition as well as degree of dissection of landscape [3]. The density network of drainage line indicates high runoff and low infiltration and vice versa. High infiltration due to the intense network of discontinuities, high porosity of rocks and soil and intensity of rainfall, increase pore water pressure and decrease the shear strength of the slope [4]. So, ratings for River/Drainage has been developed by 


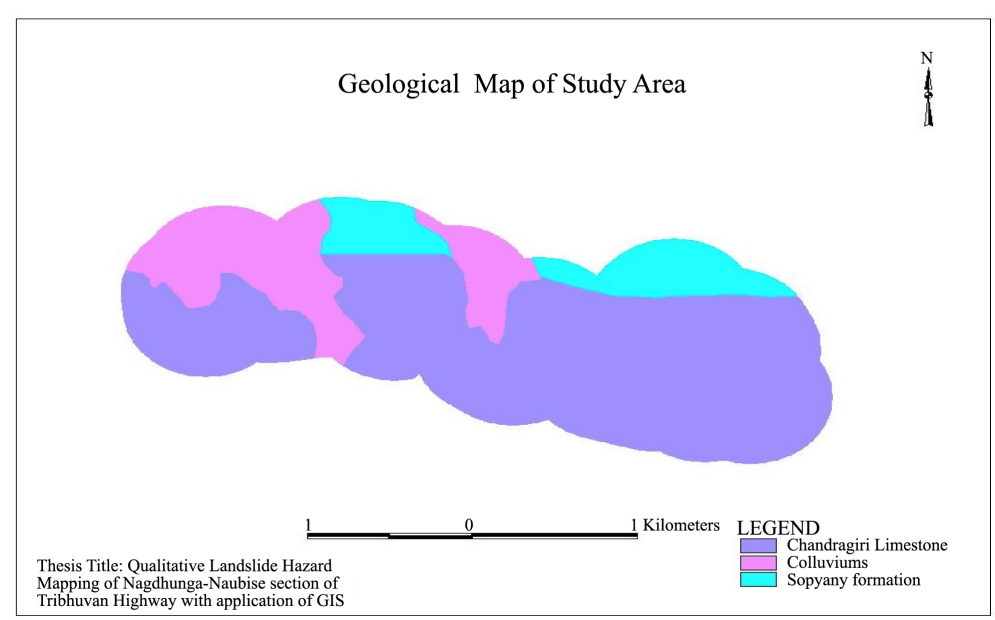

Figure 4. Proportion of different geological compositions of the study area.

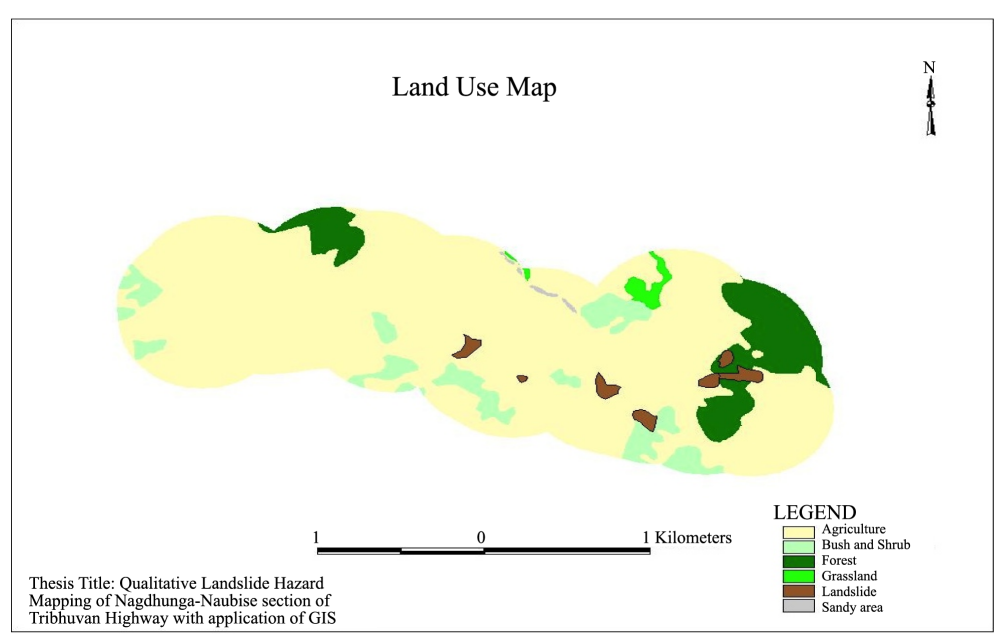

Figure 5. Land use map of the study area.

Table 2. Details of the geology of the study area.

\begin{tabular}{ccccc}
\hline SN & Geology & Rating & Area $\left(\mathrm{Km}^{2}\right)$ & Remarks \\
\hline 1 & Chandragiri Limestone & 0.6 & 3.69 & Highest Composition \\
2 & Sopyang Formation & 0.5 & 0.67 & \\
3 & Colluviums & 0.00 & 1.09 & \\
\hline
\end{tabular}

Table 3. Details of land use of the study area.

\begin{tabular}{ccccc}
\hline SN & Land Use & Rating & Area $\left(\mathrm{Km}^{2}\right)$ & Remarks \\
\hline 1 & Agriculture & 0.6 & 4.41 & Highest Area \\
2 & Forest & 0.5 & 0.51 & Lowest \\
3 & Grassland & 1.0 & 0.05 & 0.01 \\
4 & Sandy Area & 0.5 & 0.40 & 0.07 \\
6 & Sush and Shrub & 0.6 & 1.0 & \\
\hline
\end{tabular}


Mountain Risk Engineering (MRE) II handbook and engineering judgment. Figure 6 shows the river/drainage system of the study area.

\subsection{The Slope Class Map}

The enclosed slope class map depicts the assigned slope classes and their distribution in the study area. The largest portion of very gentle slopes between 0 to 20 degree is around $36 \%$, followed by areas with inclination of 40 - 90 degree, which makes up a portion of $26 \%$. Figure 7 shows the different proportions of the slope angles and Figure 8 shows the different proportions of slope shapes, which are shown below.

\subsection{The Slope Aspect Map}

The slope exposure was determined by dividing the area into 9 aspect-classes. Each class encloses an angle of 45 degrees. As presented in Table 4, the largest part of the area belongs to the flat aspect class $\left(2.18 \mathrm{Km}^{2}\right)$ and the smallest to the East aspect $\left(0.06 \mathrm{Km}^{2}\right)$. This may be due to the fact that the study area is confined to $500 \mathrm{~m}$ on either side of the road section. Figure 9 shows the proportions of different slope aspect of the study area.

\subsection{Final Hazard Map}

The percentage distribution of hazard zones and the relative landslide frequency indicates that the low class with $32 \%$, medium class is most found with $51 \%$, and high class with $17 \%$ as shown in Table 4 -Landslide distribution

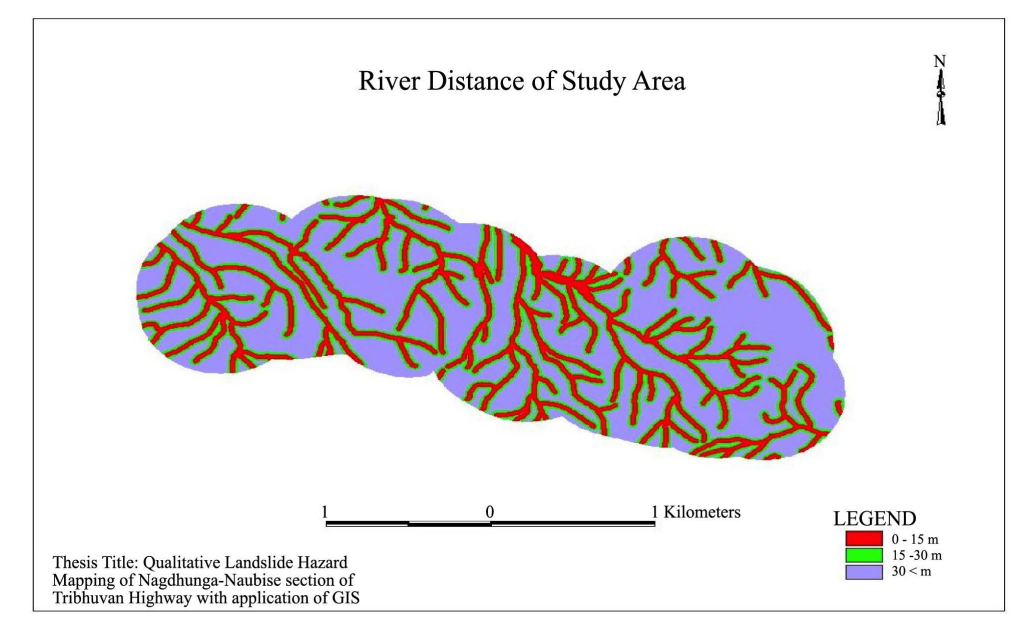

Figure 6. River/drainage system of the study area.

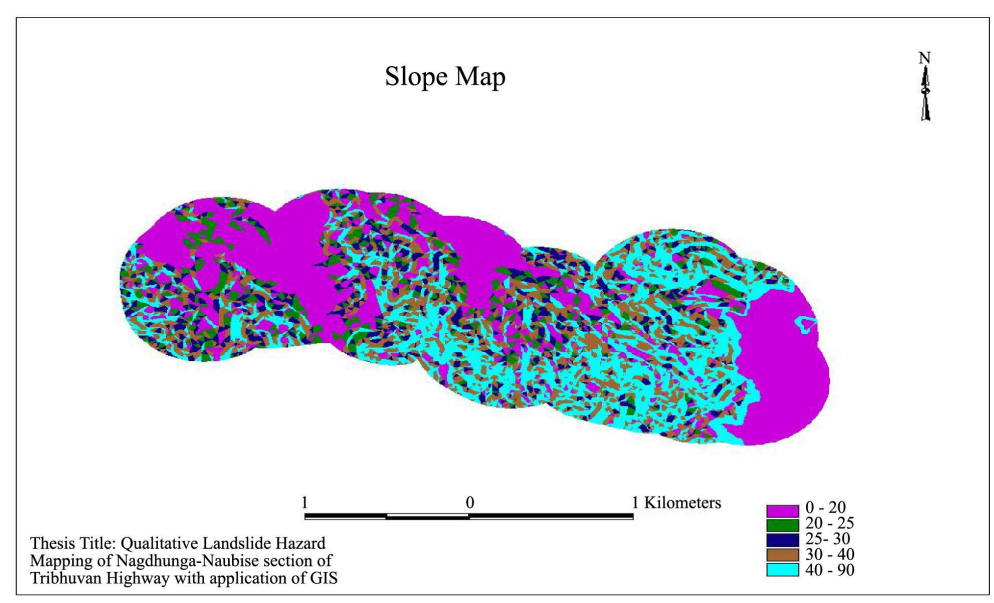

Figure 7. Proportion of different slope classes of the study area. 


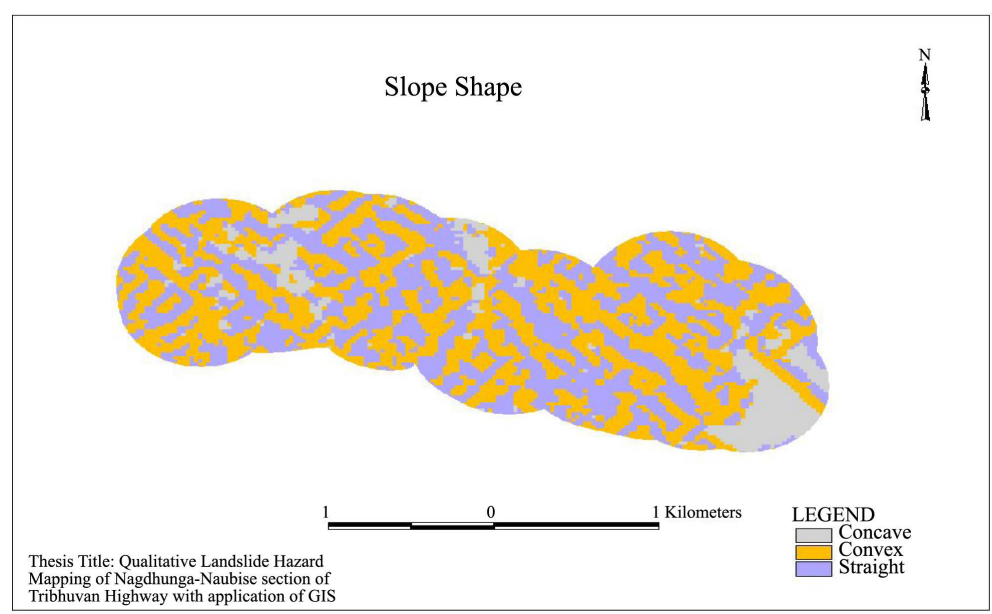

Figure 8. Proportion of different slope shapes of study area.

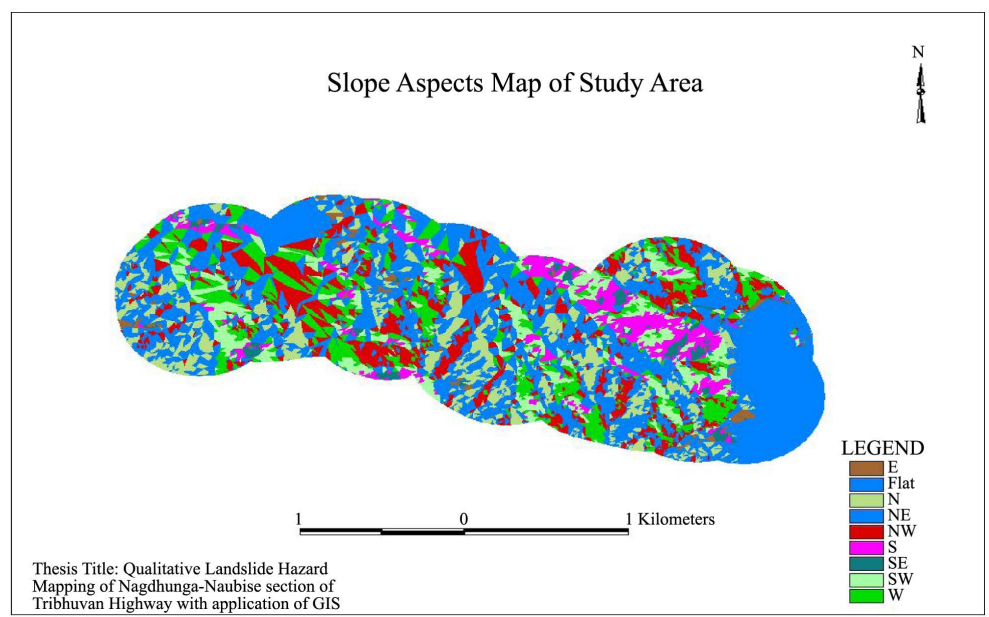

Figure 9. Proportion of different slope aspects of the study area.

Table 4. Details of slope aspect of the study area.

\begin{tabular}{ccccc}
\hline SN & Aspect & Rating & Area $\left(\mathrm{Km}^{2}\right)$ & Remarks \\
\hline 1 & Flat & 0.00 & 2.18 & Highest Area \\
2 & $\mathrm{~N}$ & 1.00 & 0.59 & Lowest \\
3 & $\mathrm{NE}$ & 1.00 & 0.24 & 0.06 \\
4 & $\mathrm{E}$ & 0.50 & 0.09 & \\
5 & $\mathrm{SE}$ & 0.00 & 0.33 & \\
7 & $\mathrm{~S}$ & 0.00 & 0.52 & \\
8 & $\mathrm{SW}$ & 0.50 & 0.70 & 0.75 \\
\hline
\end{tabular}

and percentage distribution of hazard zones and Figure 10-Final Landslide Hazard Map of the study area. Another important finding is that most of the present landslides fall under the high hazard zone of the final landslide hazard map (Figure 10). This could indication the reliability of the hazard map. 
Table 5 also shows the number of landslide counted per $\mathrm{km}^{2}$, which is a hazard potential unit. To obtain comparable values, landslide percentages were calculated per $\mathrm{km}^{2}$ hazard segments.

It should be noted that due to the small study area (about $6 \mathrm{~km}^{2}$ ) as well as small number but large size of landslides, the calculated landslide frequency is not truly representative.

\section{Conclusions}

The final hazard map shows that in the areas with hazard potential class "low" with $32 \%$ portion, "Medium" is most found with a portion of 51\% followed and "high" with the portion of $17 \%$.

The statistical analysis from the calculation of the landslide percentage per $\mathrm{Km}^{2}$ in the area is 1.1 per $\mathrm{Km}^{2}$ (highest), which is nearly equal to the value of Middle Mountain region as 1 landslide per $\mathrm{Km}^{2}$, as suggested by Wagner, 1983.

Due to the lack of important terrain information such as weathering effect, structural discontinuities, seismicity and hydrogeology were not included in the analysis. Rainfall is the main cause of failure, but it is not incorporated in the hazard rating due to the small area and the fact that it is very difficult to keep record of such variation within the small area.

The study characterizes the steep slopes: steep flow channels and fragile geology. These factors have contributed to frequent slope movement and intense erosion process during the heavy rainfall during monsoons. The developed linear infrastructure has also increased the instability of the corridor. Potentially unstable slopes were found to be high in number among steep slopes. Interestingly, the slope movement phenomenon is high in the forest as opposed to the cultivated land. The natural factors seem to have played predominant role in causing slope failures.

To obtain the slope failure potential map, data layers for each factor have been produced and superimposed. It should note that some of these superimpositions could cause the exception. In other words, it is more complex and changeable when many factors appear concurrently.

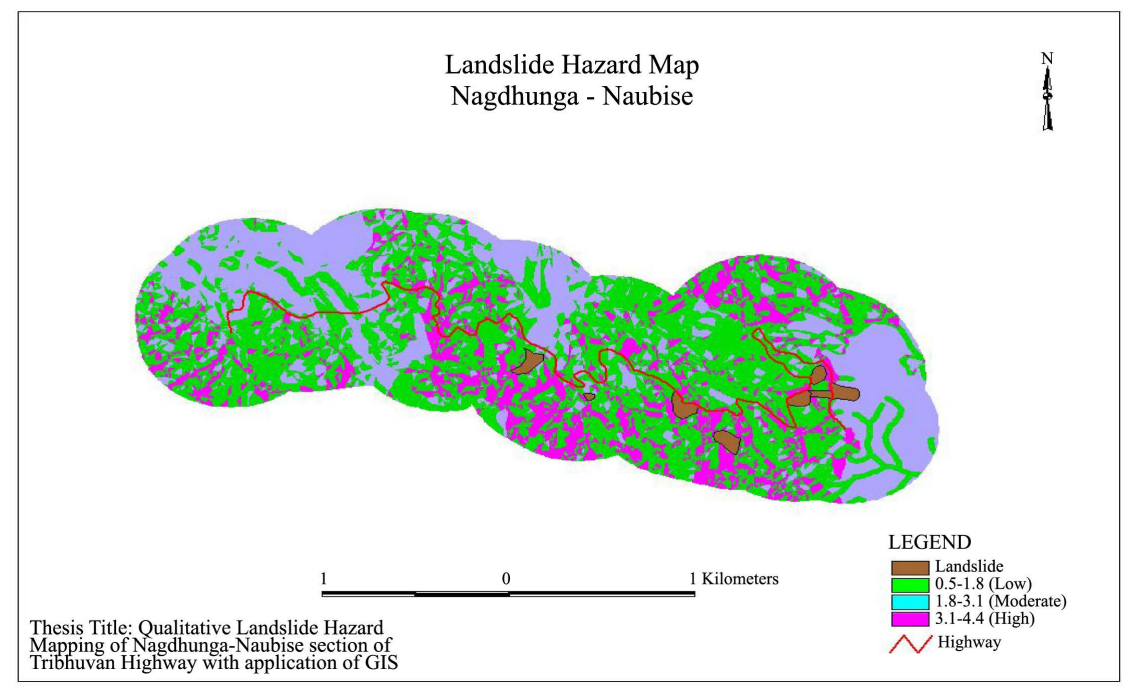

Figure 10. Final Landslide Hazard Map of the study area.

Table 5. Landslide distribution and percentage distribution of hazard zones.

\begin{tabular}{cccccc}
\hline Failure Potential & Area $\left(\mathrm{Km}^{2}\right)$ & Area (\%) & No. of Landslides & Landslide per $\mathrm{Km}^{2}$ & Landslide Percentage per Km $^{2}$ \\
\hline Low & 1.70 & 32 & 3 & 0.55 & 5.87 \\
Medium & 2.77 & 51 & 2 & 0.37 & 9.36 \\
High & 0.98 & 17 & 6 & 1.1 & 3.11 \\
Total & 5.45 & 100 & 11 & 2.02 & 18.34 \\
\hline
\end{tabular}




\section{Recommendation}

The study of hazard mapping is very useful for the mountainous country like Nepal. This will greatly help to design and construct infrastructures such as road, water supply, and hydropower projects. The application of GIS in preparing hazard mapping is even unique. This gives the ability to capture, manage, manipulate, analyze, model, and display spatially referenced data. So, it is recommended to further expand this type of study by using the technique to a larger area, which can also include critical contributors of landslide such as rainfall, weathering condition, and hydrology. Simple qualitative mapping (pre-assigned rating) method was used to produce the hazard map of the study area. In order to see the level of the accuracy of this method, it is recommended to use other methods statistical (bivariate and multivariate) and deterministic method to compare result.

\section{References}

[1] Tianchi, L., Chalise, S.R. and Upreti, B.N. (2001) Landslide Hazard Mitigation in the Hindu Kush-Himalayas. International Center for Integrated Mountain Development, Kathmandu.

[2] Wagner, A. (2000) Slope Stability Mapping of the Chandisthan Sub-Watershed, a Catchment Area of the Marsyangdi River. Halvetas/Swiss Technical Corporation Nepal, Kathmandu.

[3] Ghimire, M. (2002) Geo-Hydrological Processes and Their Impact on the Environment and Socio-Economy of a Watershed Mountain Development, Kathmandu, Nepal. International Center for Integrated Mountain Development, Kathmandu.

[4] Deoja, B., Dhatal, M., Thapa, B. and Wagner, A. (1991) Mountain Risk Engineering Handbook Part I—Subject Background. International Center for Integrated Mountain Development, Kathmandu.

[5] Deoja, B., Dhatal, M., Thapa, B. and Wagner, A. (1991) Mountain Risk Engineering Handbook Part II—Application. International Center for Integrated Mountain Development, Kathmandu.

[6] Deoja, B., Dhatal, M., Thapa, B. and Wagner, A. (1991) Risk Engineering in the Hind Kush—Himalaya. International Center for Integrated Mountain Development, Kathmandu.

[7] Department of Water Induced Disaster Prevention, Government of Nepal (2004) Report of Photo Monitoring in Kathmandu-Naubise Road. Kathmandu.

[8] Ministry of Home (2003) Annual Report. Kathmandu.

[9] Moser, M. (2002) Geotechnical aspects of landslides in the Alps. In: Rybár, J., Stemberk, J. and Wagner, P., Eds., Landslides, 24-26 June 2002, A.A. Balkema, Prague, 23-44.

[10] Sarkar, S., Kanungo, D.P. and Mehrotra, G.S. (1995) Landslide Hazard Zonation: A Case Study in Garhwal Himalaya, India. Mountain Research and Development, 15, 301-309.

[11] Schuster, R.L. and Fleming, R.W. (1986) Economic Losses and Fatalities due to Landslides. Bulletin of Association of Geologists, 23, 11-28.

[12] Sharma, C.K. (1988) Natural Hazards and Man Made Impacts in Nepal Himalaya. Puspha Sharma Publication, Kathmandu. 
Scientific Research Publishing (SCIRP) is one of the largest Open Access journal publishers. It is currently publishing more than 200 open access, online, peer-reviewed journals covering a wide range of academic disciplines. SCIRP serves the worldwide academic communities and contributes to the progress and application of science with its publication.

Other selected journals from SCIRP are listed as below. Submit your manuscript to us via either submit@scirp.org or Online Submission Portal.
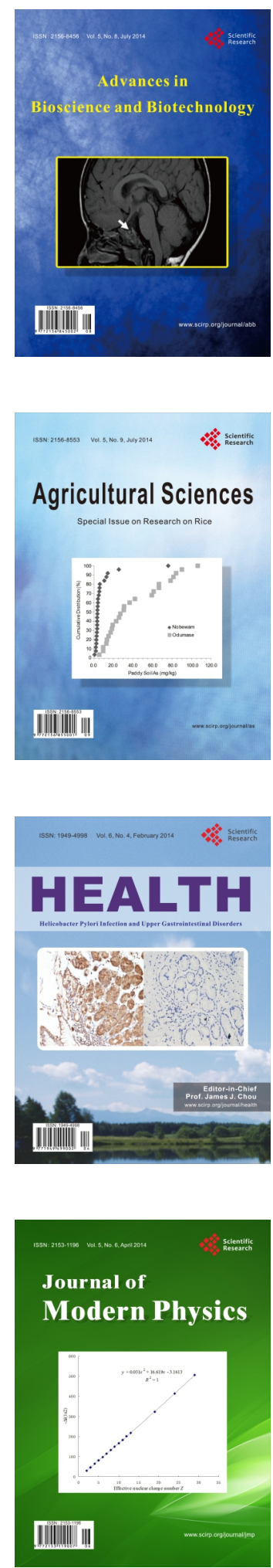
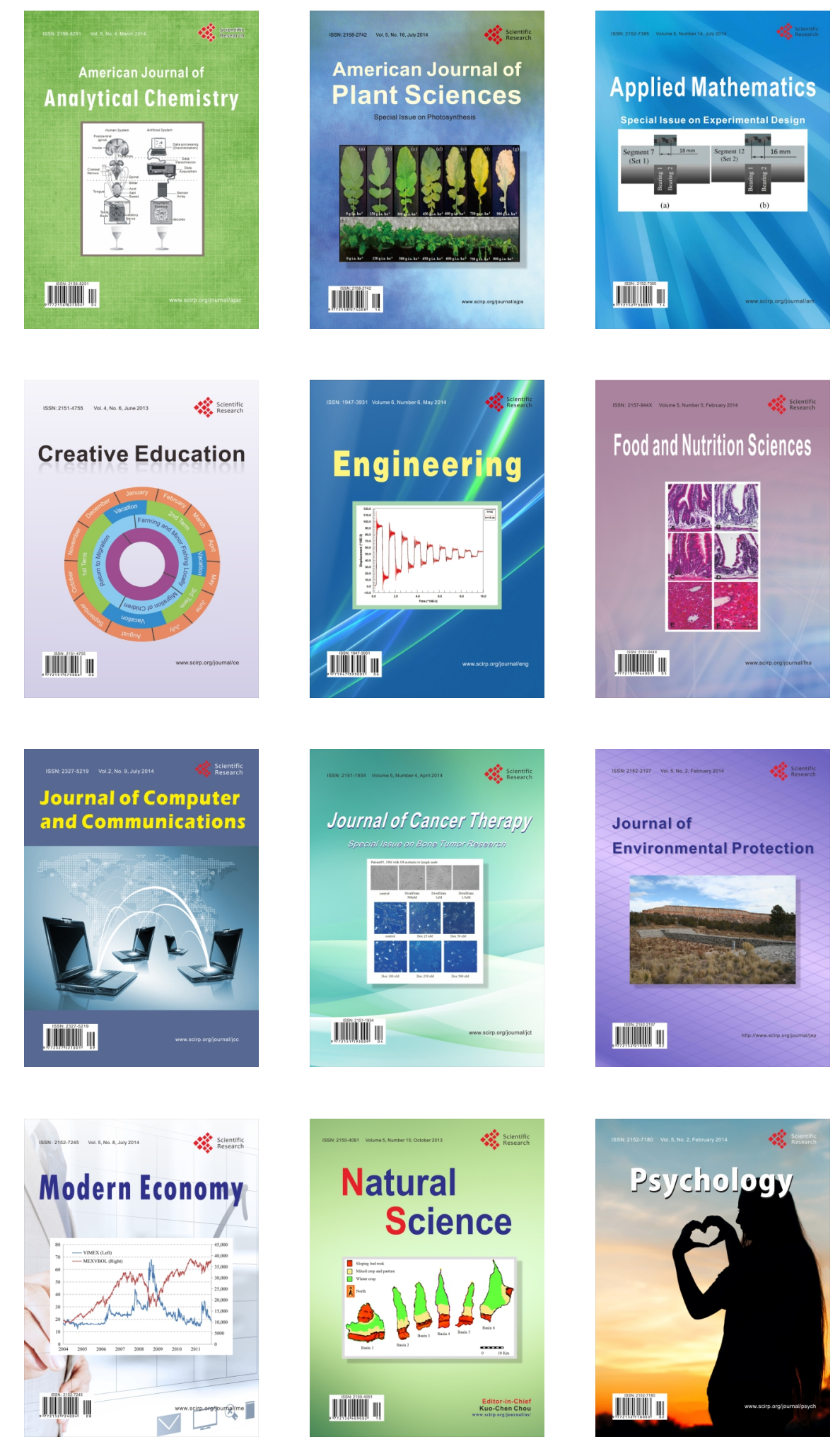